\title{
THE PROTECTION TO CHILDREN OF DUAL CITIZENSHIP IN POSSESSING TITLE ON LAND IN INDONESIA
}

\author{
Dian Arianto \\ Notary/Land Titles Registrar Batam City \\ Doctoral Degree Programe, Padjajaran University, Bandung \\ Email : dian_syaiful@yahoo.com
}

\begin{abstract}
This juridical-normative research aimed to identify and analyze the protection of the proprietary rights of children born under mixed marriages over ownership right and ownership right conveyance process for children with dual citizenship. The research results indicated that the legal protection on ownership right proprietary rights of children under mixed marriages can be applied by the children by choosing Indonesian as their citizenship at most 1 year after obtaining such bequest over the land. When the children choose foreign citizenship, then they must pass the ownership rightover the land. The transfer process on the land requires the children to be at least 18 years of age or married and cannot be represented by foreign parents/custodians, and thus a trustee is appointed based on District Court' ruling.
\end{abstract}

\section{A. INTRODUCTION}

The definition of marriage according to Article 1 of Law Number 1 of 1974 on Marriage (hereinafter called the UUP) specifies that "marriage is a physical and mental bond between a man and a woman as a couple of husband and wife with the objective to establish a happy and eternal family or household based on the Belief in the One God".

Human are created with diversities; ethnic groups, culture, and faith. Each Indonesian citizen (Warga Negara Indonesia, WNI) is entitled to be married to anyone either WNI or WNA (Foreign Nationals; Warga Negara Asing) as long as such marriage is entered in conformity to the applicable laws in Indonesia. Mixed marriage is defined in Article 57 of the UUP as "a marriage between two persons of different compliance to law due to differences of citizenship and one of the persons is a citizen of Indonesia".

Based on the definition set by Article 57 of UUP, elements of mixed marriage are as follows: (1) marriage between a man and a woman; (2) in 
Indonesia on different legislations; (3) due to differences of citizenship; (4) one is of Indonesian nationals. The first element refer to the monogamy principle in a marriage. The second element shows the differences in the law applied to each persons in the marriage. The said differences are not in faith, ethnicity, and group in Indonesia, but due to the third element, differences of citizenship. The differences of citizenship is not of foreign nationals, but due to the fourth element, that one the citizenships is Indonesian. (http://www.asiamaya.com/konsultasi_hukum/perkawinan/perk_campuran.htm, accessed on September 14 2016, 10:28 p.m.).

Indonesian community had long known the merge of marriage assets. A couple of husband and wife does not argue about the asset of each. Based on trust and understanding such merge of assets were performed, yet the merge does not prohibit each to have one's own asset. The husband's possession prior to marriage remains in the ownership of the husband despite the asset merge, and the wife is not entitled to the asset.

Joint asset is the asset obtained by either husband or wife during their matrimony for the sake of the household, thus making the asset joint asset. This is regulated by Article 35 Sentence (1) of UUP that says, "Assets obtained during wedlock become joint assets". Prenuptial agreement is made prior to a mixed marriage between a husband/wife of WNI and the wife/husband of WNA to split their individual assets. In this case, the husband/wife of WNI remains entitled to the rights over land (right of ownership) since there is no merge of assets to that of the spouse of WNA.

In relations to the children born under mixed marriage, the state of Indonesia has special provisions regulating Indonesian citizenship, i.e. the Law Number 12 of 2006 on Citizenship of the Republic of Indonesia (hereinafter referred to as Law 12/2006). The Law rules on the citizenship of mixed marriage and the children issued under the marriage. Pertaining to the legal status and the legal standing of children issued under mixed marriage, the application of Law $12 / 2006$ naturally leads to different legal consequences compared to the previous laws. 
Children issued under mixed marriage, according to Article 6 of Law $12 / 2006$, is defined as holder of dual citizenship until such children reach the age of 18 and at most within 3 years after the age of 18 or at children' marriage, the children must declare one citizenship. Dual citizenship means the children is eligible to obtain citizenship from either the father or the mother. Children of dual citizenship will have different status in land proprietorship in Indonesia. Citizens of Indonesia are entitled to the following rights: Ownership right (Hak Milik, hereinafter referred to as HM), Utilization Permit (Hak Guna Usaha, hereinafter referred to as HGU), Building Use Title (Hak Guna Bangunan, hereinafter referred to as HGB), Rights of Use (Hak Pakai, hereinafter referred to as HP), and Rights on Building Rent (Hak Sewa untuk Bangunan hereinafter referred to as HGB). Meanwhile, WNA are only entitled to the Rights of Use and Rights on Building Rent. Article 20 Sentence (1) of Law Number 5 of 1960 on the Basic Agrarian Principles (hereinafter referred to as UUPA) says that "Ownership rightis a hereditary right, the strongest and fullest of rights one may possess over land, and subject to the provisions contained in Article 6".

Issues may emerge if one of the parent with WNI status deceases and bequeaths a land with a Ownership rightstatus. Prior to marriage, a couple of WNI and WNA made prenuptial agreement thus making distinct separation of assets and the parent with WNI status is still entitled to Ownership rightover a land within Indonesian territory. Children with dual citizenship are not eligible to obtain land with Ownership rightstatus, meanwhile the land is the hereditary right of the children as the inheritor from the WNI parent.

\section{B. PROBLEM STATEMENT}

Based on the aforementioned explanation in the previous discussion, problems to be resolved in this journal are as follows:

1. How is the protection to the children born under mixed marriage in their rights over land?

2. How is the process for the conveyance of rights to the children with dual citizenship? 


\section{RESEARCH METHODS}

This research is a descriptive one, conducted by means of juridical-normative approach. The types and sources of data used are secondary data obtained through library research by studying primary and secondary legal sources. Primary legal sources are norms or basic principles (Preamble of The 1945 Constitution of the Republic of Indonesia), basic law (The 1945 Constitution of the Republic of Indonesia), TAP MPR (Ketetapan Majelis Permusyawaratan Rakyat; Resolution of the People's Consultative Assembly). Secondary legal sources were obtained from reading literatures: books, and researches related to the protection of children under mixed marriage on the rights over land.

\section{RESEARCH RESULTS AND DISCUSSION}

\section{Protection to Children under Mixed Marriage on their Title over Land}

Based on the definition of mixed marriage contained in Article 57 of UUP, one can conclude the elements of mixed marriage (Badan Pembinaan Hukum Nasional Departemen Kehakiman, 1992: 26):

1. Marriage of a couple where each complies with different marriage laws due to the difference of citizenship;

2. One of the couple is WNI;

3. Another is WNA;

4. The marriage is conducted in Indonesia;

5. Or overseas.

Article 1 of GHR (Gemengde Huwelijk Regeling; Mixed-marriage Regulation, enacted during Dutch colonial period in 1892) says that "Mixedmarriage is the marriage between persons of different submission to the law in the Dutch East-Indies". This refers to any marriage between European and indigenous Indonesian or between European and foreign Easterner or between foreign Easterner and indigenous Indonesian, and so forth (Hilman Hadikusuma, 2003: 13). 
With the implementation of the UUP, the provisions contained in GHR are null and void whilst the related provisions are regulated under the UUP. Since Article 57 of UUP empashizes the differences of citizenship and/or submission to different laws, the provision of GHR does apply as long as the performer of mixed marriage are individuals intended by Article 57 of UUP (H. Zain Badjeber, 1985: 80).

As to the persons of different citizenship who commit mixed marriage, they may obtain citizenship from the spouses and may loose citizenship according to the manners which are regulated in the applicable Indonesian citizenship Act. Such citizenship determines which law that applies - either public or private law, the status of children born from mixed marriage as regulated by the aforementioned provisions (Bachtiar Hamzah dan Sulaiman Hamid, 1997: 166-167).

According to Law 12/2006, children who are born from an Indonesian female and a foreign male as well as from a foreign female and an Indonesian male, are both acknowledged as Indonesian. Article 6 of Law 12/2006 states that:

1. The Indonesian citizenship status of children as contained in Article 4 Items c, d, h, and i, and Article 5 will effect in the dual citizenship of the child. Upon reaching the age of 18 (eighteen) or upon marriage, the child must choose one citizenship.

2. The decision to choose one of the citizenships as stipulated in Sentence (1) shall be made in writing and submitted to Officials by attaching documents as determined by regulations.

3. The decision to choose one citizenship as contained in Sentence (2) shall be made within 3 (three) years after the child has reached the age of 18 (eighteen) or the child has married.

Indonesian Civil Codes (Kitab Undang-undang Hukum Perdata, hereinafter referred to as KUHPerdata) states that a person's death cause all immediate conveyance of rights and duties to the heir(s). This is explained in Article 833 of KUHPerdata: "The heirs shall by law assume possession over 
assets, rights and claims of the deceased". Conveyance of rights and duties of the deceased to the heir(s) does not require any certain action, the same applies if the heir(s) know(s) about the said inheritance.

According to civil inheritance law, heirs are not to be distinguished by gender unlike some adat law. The principles of inheritance is bloodline, hence the heirs are persons who are related by blood to the deceased. Such relation by blood may be in the form of the relations to parent, siblings, grandmother/father, or descendants of siblings. Persons with the closest blood relations have the right to inherit, according to Article 852 of the $K U H$ Perdata:

"The children or all their descendants shall inherit from their parents, grandparents, or further blood relatives in the ascending line, without distinction between those of different sex or age, notwithstanding that they may have been conceived from several marriages. They shall each inherit equal shares, if they all are from the same level and are summoned on their own behalf; they shall inherit by branches of the main stock, if all or part of them present themselves by substitution".

The legal consequences of mixed marriage affect marriage assets, both assets that had previously been obtained before marriage and assets obtained during marriage. According to the law, the status of marriage assets depends on whether there had been prenuptial agreement made before the marriage (Wahyono Darmabrata, 2009: 128). In a mixed marriage without prenuptial agreement, all assets obtained during marriage become joint assets except the couple in the marriage had made prenuptial agreement prior to the marriage to avoid legal merge of asset. Article 21 Sentence (1) of UUPA says that "Only citizens of Indonesia are entitled to have right of ownership". For a WNI married to a WNA, it will be difficult to own land or building with HM status if the marriage is not preceded with a prenuptial agreement. This is because UUP in Indonesia regulates that assets obtained during marriage become joint assets, where a WNA spouse will also share ownership with the WNI spouse, meanwhile UUPA says that WNA are not entitled to have land with HM status. If during marriage the WNI spouse obtains HM, HGB, HGU, Ownership on Tenement Unit on HGB land, either from bequest, conveyance 
of rights due to purchase, grant, or testamentary, then the person of WNI citizenship must exonerate his/her rights within 1 year since obtaining the rights.

Exoneration of rights may be exercised by means of selling, granting the rights on the land, or diminishing the status of the land into Rights of Use (Hak Pakai, HP). If the term 1 year passed, the rights are acquitted since the law and the land returns to the state under a provision that the rights of other encumbering parties remain. However, the state is an exception to the rights of saisine, where the state is the only heir without saisine right. Saisine right is the right earned by an heir automatically on every items, all rights and claims, as well as the liabilities of the testator. Hence, the conveyance of rights and duties of the deceased to the state does not arise as matter of law. In order for the conveyance to arise, the state must perform certain legal acts as contained in Article 833 Sentence (3) of the KUH Perdata.

Children with dual citizenship have the options to maintain an HM inheritance from the parents, i.e. by choosing WNI as their citizenship. However, if after 1 year a dual-citizenship inheritor child does not choose WNI as citizenship, s/he is not entitled to have HM over the inheritance from the WNI parent.

The first thing to beware of in mixed marriage is the legality of the mixed marriage itself; is it valid and meeting the requirements of applicable laws in Indonesia, since many Indonesians marry foreign nationals only for contract marriage (Arabic: Mut'ah, Indonesian: kawin kontrak), thus making it unregistered as legit marriage according to applicable laws in Indonesia. If the mixed marriage is a contract marriage then the status of a child born under such matrimony will be considered illegitimate and the child will only have civil law relations to the mother. A different case will occur if the mixed marriage is performed in accordance with the applicable laws in Indonesia; the marriage is legit and the children born under such marriage are legally related to both parents.

European inheritance law contained in Burgerlijk Wetboek (BW; 
English: Civil Codes) is a compilation of rules on assets due to the death of a person, i.e. on the conveyance of assets left by the deceased and the consequences of such conveyance to the persons who obtain the assets, as well as their dealings with the third party (A. Pitlo, 1979: 1). Elements of inheritance must contain the following requirements:

1. There is a deceased;

2. There are living persons, as inheritors who will obtain inheritance at the moment the testator passes away;

3. There is a number of assets left by the testator.

Inheritance law, according to BW is with a principle "when somebody dies, all his/her rights and duties are immediately conveyed to the inheritors" (R. Subekti, 1977: 79). The definition of HM in UUPA is formulated in Article 20 Sentence (1) i.e. "A right of ownership is a hereditary right, the strongest and fullest right on land that one can hold, subject to the provision contained in Article 6”.

Hereditary right means that the object can be passed to the inheritor of the person who owns a land. This means that the term of HM is undetermined, unlike HGB and HGU. HM will not only last during the life of the person who owns it, but the ownership will also be continued by the inheritor. A land that becomes the object of HM is permanent, which means the object on which the right of ownership stands is still similar (Adrian Sutedi, 2006: 61). The strongest means that the right is not easily exonerated and that it may be easily defended towards the disturbances from other parties, hence, such right must be registered (Adrian Sutedi, 2006: 67-68). 'The strongest' may also refer to the unlimited term of HM.

A child of dual citizenship from parents of WNI status and has not reached adulthood is not eligible to possess $\mathrm{HM}$ over land according to Article 21 Sentence (4) of UUPA, and within 1 year after inheriting HM over land, such inheritor must convey the inheritance to other party. Such conveyance may take the form of sales, or degrading the right from HM to HP as the child is still of dual citizenship and only allowed to have HP and 
Rent Right on buildings despite the fact that the inheritance is his/her right as the inheritor of his/her parents who are of Indonesian citizinship. There is no legal basis that guarantees the child to maintain his/her HM on the inherited land, unless within 1 year after the child obtains the inheritance s/he chooses citizenship into WNI.

Pertainining to the conveyance of HM over land, the child must present a certificate stating that $\mathrm{s} / \mathrm{he}$ is the inheritor; for Chinese descent, an inheritor certificate issued by a notary and for foreign easterners, an inheritor certificate issued by Property and Heritage Agency. If the child is still under the age of 18, in process of administrating deeds and paper works related to such conveyance, the child must be under the custody of the parent. However, if the living parent is WNA, then the administration custody on the child of dual citizenship is appointed by means of court's ruling.

The following is the principle rights of inheritor:

1. Saisine right

This right is automatically held by an inheritor on every item, all rights and claims, as well as liabilities of the testator.

2. Hereditatis Petitio

This right is held by the inheritor to claim assets occupied by others to be included in the inventory of inheritance.

3. Right to Claim Inheritance

This right is regulated under Article 1066 of KUHPerdata and this right is absolute.

A person who owns a HM on a land, after he dies the HM on the land shall automatically conveyed to the legit inheritor. This automatic conveyance is called Saisine Right. The state is the only inheritor that is not in possession of Saisine Right. The conveyance occur as a matter of law at the moment the holder of the right dies, which means, since the death of the right holder, there is new holder of the right towards the assets of the testator.

Indonesian estate law is under the principle of gronds verponding verbood (land pardon prohibition) which means estates in Indonesia are not to 
be owned by persons with other citizenship than Indonesian. This is the concept of the state that basically the land/estates in Indonesia is a gift from God the Almighty and it belongs to the Indonesian people. The principle aims to protect Indonesian estates that it should not be possessed by other nationals. This prohibition serves to protect earth, air, space, and natural resources from foreign possession, and exploitation, as well as to prevent the transmission of the profit of Indonesian agrarian resources, such as estates which originally is meant for the greatest interest and profit of the Indonesian people (Fx. Sumarja, 2012: 22).

A child of dual citizenship have the option to maintain inheritance from parents over an estate; by choosing citizenship of Indonesian. By choosing WNI, s/he reserves the right to maintain the HM on the estate. If the child does not choose citizenship within 1 year after inheriting, s/he will remain in dual citizenship, and will not be entitled to obtain HM on the inherited estate. The child must convey his/her right either by degrading the right into HP or sell it to another party. If none of the above is conducted by a child of dual citizenship then the HM of the estate shall automatically go to the state and the estate becomes state property.

\section{Process of Conveyance of Rights on Estate towards a Child of Dual Citizenship}

Requirements for legit agreement according to Article 1320 of KUHPerdata:

1. The parties agree to bind themselves;

2. Legally competent to bind themselves;

3. On a certain matter;

4. Of a proper cause.

According to the provisions of Article 1330 of KUHPerdata, persons not competent to make an agreement is:

1. Underage persons;

2. Being under guardianship; 
3. Wives, in matters stipulated by law and in general persons to whom the law prohibit them to make certain agreement.

An adult person, due to mental and physical impairment or imperfection is at the same level with an underage person (R. Soetojo Prawirohamidjojo and Marthalena Pohan, 1991: 237). Article 452 of KUHPerdata says that "Everyone being put under guardianship is of similar level to and underage". According to the provisions contained in Article 433 of KUHPerdata, there are 3 causes of guardianship (R. Soetojo Prawirohamidjojo and Marthalena Pohan, 1991: 237):

1. Wastefulness (verkwisting);

2. Weakness of ability (zwakheid van vermogen), for instance imbecility;

3. Lack of ability in thinking, insanity (krankzinnigheid), stupidity (onnozelheid), and stupidity with tendency to rage (razernij).

In principle, parent with the longest lifespan is automatically or by matters of law the custodian/guardian for his/her underage child. The folloing are 3 kinds of guardianship:

1. Guardianship by husband or wife who lives longer. This provision is contained in Article 345 of the KUH Perdata, yet this Article does not make exception to couples who live separately due to interruption of marriage due to divorce or separation of bed and board. Hence when the father after the divorce becomes the custodian, upon his death the mother by matters of law becomes the custodian of the children.

2. Guardianship through appointment by father or mother by means of will or separate deed.

This is regulated under Article 355 Sentence (1) of KUHPerdata:

"Each of the parents, who exercises parental authority or guardianship over one or more children, shall be entitled to appoint a guardian for those children in the event that after 
his or her death the guardianship is not assigned to the other parent by law or pursuant to the legal decree mentioned in the final paragraph of article 353"

In other words, each parent who exercises guardianship or holds parental authority bears the right to appoint a guardian if such guardianship is still open.

3. Guardianship through Judge' appointment.

This is regulated by Article 359 Sentence (1) KUHPerdata:

"In respect of all minors who are not under parental authority and whose guardianship has not already been provided for by law, a guardian shall be appointed by the court of justice after having heard or properly summoned the blood relatives or relatives by marriage".

(http://repository.usu.ac.id/bitstream/123456789/1520/3/perdatasunarto2. pdf.txt; accessed on July 82015 at 12:08).

The provision that a person acts as guardian over underage children is contained in Articles 309 and 393 of KUHPerdata. The Articles determine that an act of conveying or creating the assets of underage children must be through the consent of District Court. In a case where a guardian will convey or create the assets of underage children must previously submit an application for the appointment as guardian and for being given the permit to sell or create the asset to the local District Court as basis of the authority to conduct the legal action.

Several legislations regulate the age limit of adulthood and competence to conduct legal action. Article 47 of UUP states that "a person under the age of 18 years or who has never been married is under the authority of his/her parents for as long as such authority has not been revoked". Article 39 Sentence (1) of Law Number 2 of 2014 on the Amendment to Law Number 30 of 2004 on the Notarial Post states "Parties appearing must meet a requirement of at least 18 years of age or being married and competent in performing legal actions". The Circular of the Minister of Agraria and Spatial 
Affairs/Head of National Land Affairs Agency Number 4/SE/I/2015 on the Limitation of Adulthood Age in terms of Land Affairs Services states that a person is eligible to perform legal action in the course of land affairs services is 18 years of age or being married.

For a child from mixed marriage with dual citizenship, the child must be represented by guardian in the making of deeds unless the child has chosen Indonesian as his/her citizenship, thus in the issuance of inheritor's certificate s/he no longer needs guardian. If the child moves to do conveyance over his/her property, the child with dual citizenship must be represented by a guardian appointed by District Court's ruling. A child from mixed marriage with dual citizenship may act in a collation (Dutch: comparitie) if s/he is represented by a guardian appointed through guardianship appointment from District Court on the conveyance due to selling the asset inherited from parents.

A person who has reached adulthood yet due to physical and mental condition that makes him/her deemed defective stands that the same level of an underage child (R. Soetojo Prawirohamidjojo and Marthalena Pohan, 1991: 237). A person is deemed legally competent when s/he meets/exceed the age limit as previously discussed and is considered competent to perform a legal action. Underage child must be represented by a guardian who had previously apply an appointment of guardianship and consent to creation of assets to the local District Court as a legal basis for the subsequent legal actions. The provisions pertaining to asset conveyance or creation that belongs to an underage child is contained in Articles 309 and 393 of KUHPerdata. The age limit set for the process of legal deed pertaining inheritance for underage child from mixed marriage is quite similar to the age limit set for making legal deed for a child of a single WNI. The difference is in the action authority of parents. The child of a single WNI may be represented by his/her parents, meanwhile the underage child from a mixed marriage cannot be represented by a WNA parent in terms of making deeds for the conveyanve of right on land. 
A person is declared legally competent when s/he performs a legal action within the provision of age as previously discussed. Article 50 of UUP states that "any child who has not reached 18 years of age or is unmarried, not under the authorities of parent, shall be under the authority of a guardian". About parental authority, Article 47 Sentence (1) of UUP states that "a child under the age of 18 years or who has never been married is under the authority of his/her parents for as long as such authority has not been revoked". Article 47 Sentence (2) of UUP later regulates that parent represent the child in any legal actions in and out of court. Meanwhile Article 49 of UUP contains provision pertaining the revocation of parental authority due to negligence or appalling behaviour.

If an underage child wishes to convey the HM on an estate inherited from a deceased parent, s/he must be represented by the remaining parent whose authority has not been revoked. The parent must apply an appointment from local District Court to act as agent to convey the HM on the estate. Such appointment serves as a legal basis for the parent to perform legal action. The provisions ruling on the conveyance and creation of assets that belong to an underage child are contained in Articles 309 and 393 of KUHPerdata. The age limit set for the process of legal deed pertaining inheritance for underage child from mixed marriage is similar to the age limit set for making legal deed for a child of a single WNI. The difference is in the action authority of parents. The child of a single WNI may be represented by his/her parents, meanwhile the underage child from a mixed marriage cannot be represented by a WNA parent in terms of making deeds for the conveyanve of right on land. The difference is in the action authority of parents. The child of a single WNI may be represented by his/her parents, meanwhile the underage child from a mixed marriage cannot be represented by a WNA parent in terms of making deeds for the conveyanve of right on land. This is in line with Article 21 Sentence (1) of UUPA; only WNI are allowed to possess HM on an estate, making the WNA parent of a child from mixed marriage illegitimate to be the guardian for the child in the making of deed for the conveyance of HM on an 
estate.

\section{E. CLOSSING}

\section{Conclusion}

a. Legal protection to children from mixed marriage on Ownership Right on an estate may be exercised by the child; i.e. by choosing to become WNI as his/her citizenship within 1 year after inheriting the Ownership Right. However, if the child moves to choose WNA as citizenship, the provision of Article 21 Sentence (3) of UUPA applies to the child. The Article states that within the said 1 year the child must move the Ownership Right on the estate, making the inheritance right to retain the ownership right on the estate void.

b. Process of conveyance of right on an estate that belong to a child of dual citizenship is similar to that of WNI with single citizenship; 18 years old or married and cannot be represented by parents of WNA status. Hence, a guardian must be appointed by District Court's ruling.

\section{Suggestions}

a. For citizens of Indonesia, when they want to be married to a foreign national, it is suggested that they make prenuptial agreement which will enable them to retain ownership right on their estates in Indonesia.

b. It is expected that more socialization is conducted to WNI who are married to WNA that Law Number 12 of 2006 on the Citizenship of the Republic of Indonesia allows limited dual citizenship for children from mixed marriage.

\section{BIBLIOGRAPHY:}

\section{Books:}

Badjeber, H. Zain, 1985, Tanya Jawab Masalah Hukum Perkawinan (Q\&A on Marriage Law), Jakarta: Sinar Harapan.

Darmabrata, Wahyono, 2009, Hukum Perkawinan Perdata Syarat Syahnya 
Perkawinan Hak dan Kewajiban Suami Isteri Harta Benda Perkawinan (Civil Marriage Law. Requirements of Marriage Legitimacy. Rights and Duties of Couples. Marriage Assets), Jakarta: Rizkita

Hadikusuma, Hilman, 2003, Hukum Perkawinan Indonesia (Indonesian Marriage Law). Bandung: Mandar Maju.

Hamzah, Bachtiar \& Sulaiman Hamid, 1997, Hukum Internasional II (International Law II), Medan: USU.

Prawirohamidjojo, R. Soetojo and Marthalena Pohan, 1991, Hukum Orang dan Keluarga: Personen en Familie-Recht (Law on Persons and Family), Surabaya: Airlangga University Press.

Pitlo, A, 1979, Hukum Waris Menurut Kitab Undang-Undang Hukum Perdata. Terjemahan M. Isa Arief (Inheritance Law According to The Book of Civil Codes), Jakarta: Intermasa.

Subekti, R, 1977, Pokok-Pokok Hukum Perdata (Principles of Civil Law). Jakarta: Intermasa.

Sumarja, Fx, 2012, Problematika Kepemilikan Tanah Bagi Orang Asing (Problems Surrounding Estate Ownership for Foreign Nationals.), Bandar Lampung: Indepth Publishing.

\section{Article/Journals}

Badan Pembinaan Hukum Nasional Departemen Kehakiman. 1992/1993. Laporan Akhir Pengkajian Hukum Tentang Perkawinan Campuran (Dalam Hukum Perdata Internasional) (Final Report, the Research on Mixed Marriage (in International Civil Law)). Departemen Kehakiman Badan Pembinaan Hukum Nasional. Jakarta

\section{Regulations}

Law Number 5 of 1960 on Basic Agrarian Principles, Indonesian State Gazette of 1960 Number 164 and Supplement to the State Gazette of the Republic of Indonesia Number 2043

Law Number 1 of 1974 on Marriage, Indonesian State Gazette of 1974 Number 1 and Supplement to the State Gazette of the Republic of Indonesia Number 3019.

Law Number 12 of 2006 on Citizenship of the Republic of Indonesia, Indonesian State Gazette of 2006 Number 63 and Supplement to the State Gazette of the Republic of Indonesia Number 4634.

Law Number 2 of 2014 on the Amendment of Law Number 30 of 2004 on Notarial Post, Indonesian State Gazette of 2014 Number 3 and Supplement to the State Gazette of the Republic of Indonesia Number 5491.

The Circular of the Minister of Agraria and Spatial Affairs/Head of National Land Affairs Agency Number 4/SE/I/2015 on the Limitation of Adulthood Age in terms of Land Affairs Services.

\section{Website:}

http://www.asiamaya.com, accessed on September 142016. 